\title{
Apparent vaccine-thimerosal induced hypersensitivity, myelodysplastic syndrome and pancytopenia
}

\author{
Hasan Karsen, ${ }^{1}$ Hayrettin Akdeniz, ${ }^{2}$ Mustafa K. Karahocagil, ${ }^{2}$ Ali İ. Baran, ${ }^{2}$ Remzi Erten. ${ }^{3}$ \\ ${ }^{1}$ Infectious Diseases and Clinical Microbiology, Hakkari State Hospital, Hakkari, Turkey; ${ }^{2}$ Department of Infectious Diseases and \\ Clinical Microbiology, Yüzüncü Yıl University, Van, Turkey; ${ }^{3}$ Department of Pathology, Yüzüncü Yıl University, Van, Turkey.
}

\begin{abstract}
A case of hypersensitivity reaction, myelodysplastic syndrome and pancytopenia, which developed after an administration of thimerosal-containing tetanus vaccine, is presented and discussed.

Key Words: Thimerosal, hypersensitivity reaction, myelodysplastic syndrome, pancytopenia.

J Infect Developing Countries 2007; 1(3):348-349.

Received 12 July 2007 - Accepted 7 November 2007.

Copyright (C) 2007 Karsen et al. This is an open access article distributed under the Creative Commons Attribution License, which permits unrestricted use, distribution, and reproduction in any medium, provided the original work is properly cited.
\end{abstract}

\section{Introduction}

Thimerosal is used as a preservative for many vaccines, and so is one of the most important organic mercury compounds to which human populations are exposed. Despite evidence of toxicity, the World Health Organization (WHO) continues to recommend the use of thimerosalcontaining vaccines, especially those available in multidose vials, in countries that do not have resources for alternative vaccine preparations because the benefit-cost ratio remains very high [1]. The following report presents an account of probable thimerosal toxicity induced by vaccination in an adult woman.

\section{Case}

A forty-three-year-old woman was admitted to our department on May 1, 2006, with a history of tetanus vaccination one month previously. Immediately following vaccination she experienced difficulty in breathing, chest tightness, headache and facial flushing. Swelling started in the periorbital area, and over the next 3 days spread to her shoulders and arms, eventually affecting the whole body. She reported general fatigue and malaise and noted a jaundiced appearance. These symptoms decreased within one month but did not completely disappear. When she was referred to our department one month later, she had still facial swelling and flushing, together with jaundice and profound weakness and fatigue.

Physical examination revealed moderate general status, ill appearance, with facial swelling and flushing, especially in the periorbital region. Her blood pressure was $110 / 80 \mathrm{mmHg}$, pulse rate 86 /minute, and respiration rate 20 /minute; other systems were normal. Urinalysis was normal. Haematological findings were WBC $2600 / \mathrm{mm}^{3}$, hemoglobin 4.2, g/dl, hematocrit 16\%, MCV 60, platelets $53.000 / \mathrm{mm}^{3}$, PT $13 \mathrm{sec}$, and PTT $34 \mathrm{sec}$, fibrinogen $259 \mathrm{mg} / \mathrm{dl}$, ferritin $<1.5 \mathrm{ng} / \mathrm{ml}$, serum iron $14.4 \mu \mathrm{g} / \mathrm{dl}$, serum iron binding capacity 287 $\mu \mathrm{g} / \mathrm{dl}$, vitamin B12 $379 \mathrm{pg} / \mathrm{ml}$, folate $5 \mathrm{ng} / \mathrm{ml}$. Blood biochemistry showed ALT $12 \mathrm{U} / \mathrm{L}$, AST 14 $\mathrm{U} / \mathrm{L}$ and AFP $0.8 \mathrm{ng} / \mathrm{ml}$. Faecal examination showed no occult blood or parasites. Serological examination for a wide variety of bacterial and viral infections showed only a positive HAV lgG, and malignancy and autoimmune markers were negative. Abdominal ultrasonography showed normal liver size, but the liver parenchyma had a heterogeneous appearance with a granular pattern and liver biopsy showed non-specific hepatitis. Changes consistent with myelodysplastic syndrome were observed in a bone marrow biopsy.

The vaccine given was produced at the Serum Institute of India Ltd and contained the standard $0.01 \%$ thimerosal as a preservative against 
bacterial contamination. The clinical presentation was consistent with adverse reaction to mercury, and since the only confirmed exposure to mercury was the thimerosal in the tetanus vaccine, we concluded that the symptoms probably resulted from toxic effects of thimerosal and that this was a case of vaccine-induced toxicity. Following supportive and symptomatic treatment, including oral iron to increase hemoglobin, the patient showed complete recovery from symptoms within one month. Repeated liver ultrasound was evaluated as normal, and laboratory findings were within normal ranges. Repeated bone marrow examination showed some improvement, but evidence of myelodysplastic syndrome continued, and the patient was transferred to the care of the Haematology Department for long-term follow up.

\section{Discussion}

Thimerosal is an ethyl mercury derivative used as a preservative to prevent bacterial contamination of multidose vaccine vials after they have been opened [2]. Potential problems resulting from the use of this preservative have been a matter of recent discussion, with evidence of toxicity in mice [3], and of induction of apoptosis in cell cultures [4]. Increased risk of autism, speech disorders, mental retardation, personality disorders, and thinking abnormalities have been reported to the Vaccine Adverse Event Reporting System following the adminsitration of thimerosalcontaining diphtheria-tetanus-pertussis (DTaP) vaccines in comparison to thimerosal-free DTaP vaccines $[5,6]$. Exposure to low doses of thimerosal has also been associated with hypersensitivity reactions and allergy [7].

We suggest that considering the rapid development of symptoms following vaccination, the thimerosal in the vaccine was responsible for bone marrow toxicity, resulting in pancytopenia, and for hypersensitivity reactions including edema and dyspnea. Most clinical studies on vaccineinduced toxicity have been conducted on children, and the presentation of this case should alert physicians in countries where adult vaccination campaigns are carried out to the possibility of thimerosal-induced toxicity.

\section{References}

1. Hessel L (2003) Mercury in vaccines. Bull Acad Natl Med 187: $1501-10$.

2. Clements CJ and Mc Intyre PB (2006) When science is not enough - a risk/benefit profile of thiomerosalcontaining vaccines. Expert Opin Drug Saf 5: 1745(9):657-66.29.

3. Havarinasab $S$ and Hultman $P$ (2006) Alteration of the spontaneous systemic autoimmune disease in (NZB $x$ $\mathrm{NZW}) \mathrm{F} 1$ mice by treatment with thimerosal (ethyl mercury). Toxicol Appl Pharmacol 214: 43-54.

4. Woo KJ, Lee TJ, Bae JH, Jang BC, Song DK, Cho JW, Suh SI, Park JW, Kwon TK (2006) Thimerosal induces apoptosis and $\mathrm{G}(2) / \mathrm{M}$ phase arrest in human leukemia cells. Mol Carcinog 45: 657-66.

5. Madi A (2005) Being on the track of thimerosal Acta Microbiol Immunol Hung 52: 95-103.

6. Geier DA and Geier MR (2005) A two-phased population epidemiological study of the safety of thimerosalcontaining vaccines: a follow-up analysis. Med Sci Monit 11: $160-170$

7. Kiec-Swierczynska M (1996) Mercury as an allergic factor. Med Pr 1: 77-81.

Corresponding Author: Hasan Karsen, Infectious Diseases and Clinical Microbiology, Hakkari State Hospital, 30000 Hakkari, Turkey, Phone: + 90438211 4512, Fax: 432 2167519, hasankarsen@hotmail.com

Conflict of interests: The authors declare that they have no conflict of interests. 